\title{
Catalytic Synthesis of Pyrano- and Furoquinolines Using Nano Silica Chromic Acid at Room Temperature
}

\author{
Ali Gharib ${ }^{1,2}$ and Manouchehr Jahangir ${ }^{1}$ \\ ${ }^{1}$ Department of Chemistry, Islamic Azad University, Mashhad, Iran \\ ${ }^{2}$ Agricultural Researches and Services Center, Mashhad, Iran \\ Correspondence should be addressed to Ali Gharib; organiccatalyst2008@gmail.com
}

Received 29 August 2012; Revised 2 October 2012; Accepted 16 April 2013

Academic Editor: Chao Jun Li

Copyright (C) 2013 A. Gharib and M. Jahangir. This is an open access article distributed under the Creative Commons Attribution License, which permits unrestricted use, distribution, and reproduction in any medium, provided the original work is properly cited.

Nano silica chromic acid (nano-SCA) is found to catalyze efficiently the three component-coupling reactions of aldehydes, amines, and cyclic enol ethers such as 3,4-dihydro-2H-pyran and 2,3-dihydrofuran under mild conditions to afford the corresponding pyrano- and furanoquinolines in excellent yields with high endoselectivity. Interestingly, 2,3-dihydrofuran afforded selectively endoproducts under the similar reaction conditions. Heterogeneous reaction conditions, easy procedure, short reaction time, and high yields are some important advantages of this method.

\section{Introduction}

Aza-Diels-Alder reactions rank among the most powerful methodologies for the construction of nitrogen-containing six-membered ring compounds [1]. The pyranoquinolines and furanoquinolines are a class of nitrogen-containing heterocycles which are synthesized by Aza-Diels-Alder methodology. Whereas pyranoquinolines exhibit biological properties such as psychotropic, antiallergic, anti-inflammatory, and estrogenic activities in addition to their use as pharmaceuticals $[2,3]$, the furanoquinolines function as antagonists of 5-hydroxytryptamine receptors in animals and have been found to be the most potent anti-inflammatory agents in addition to being the most potent anti-inflammatory agents [4]. The hetero-Diels-Alder reaction is becoming a mainstay for heterocycle and natural product synthesis $[5,6]$. Pyranoquinoline derivatives are found to possess a wide spectrum of biological activities such as psychotropic, antiallergenic, anti-inflammatory, and estrogenic activity [7].

Generally these compounds are prepared by Aza-DielsAlder reactions of imines derived from aldehydes and amines with dihydropyran or dihydrofuran. Transition-metal complexes such as $\mathrm{Co}_{2}(\mathrm{CO})_{8}, \mathrm{Ni}(\mathrm{CO})_{4}[8,9]$, and $\mathrm{InCl}_{3}[8,9]$ find their use for this reaction, although $\mathrm{BF}_{3} \cdot \mathrm{OEt}_{2}$ has been the most commonly used catalyst. Thirteen various methods
[10] are reported in the literature which include the use of $\mathrm{GdCl}_{3}, \mathrm{ZrCl}_{4}, \mathrm{LiClO}_{4}, \mathrm{LiBF}_{4}, \mathrm{I}_{2}$, and montmorillonite clay to promote this reaction. Many Lewis acids cannot be utilized for the single-step coupling of aldehydes, amines, and enol ethers because they will be decomposed or deactivated by the amines and water formed in the intermediate imineformation step. Most imines are hygroscopic, unstable at high temperature, and difficult to purify; so, a one-pot three-component coupling protocol is highly desirable. Nano silica chromic acid (nano-SCA) is a solid acid which can be used for different reactions either as reagent or as catalyst under heterogeneous conditions. Collective nano-SCA would be a superior proton source and is comparable with other solid acids such as nafion- $\mathrm{H}$, silica sulfuric acid, and silica chloride [11-17]. In this paper, we wish to present a simple one-pot protocol for synthesis of pyrano[3,2-c] quinolines and furano quinolines using nano-SCA, benzaldehyde, aniline, and 3,4dihydro- $2 H$-pyran in THF as solvent and room temperature conditions.

\section{Experimental}

The chemicals used in the synthesis of all dyes were obtained from Merck chemical company and were used without further purification. The melting points were obtained using an 


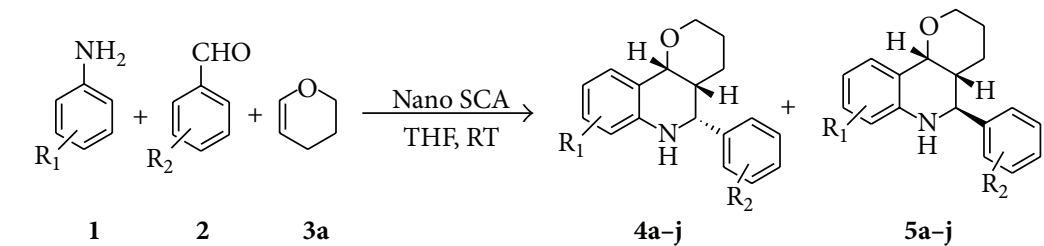

Nano silica chromic acid (Nano SCA)

SCHEme 1: Synthesis of pyrano[3,2-c] quinolines using nano silica chromic acid (nano-SCA) catalyst.

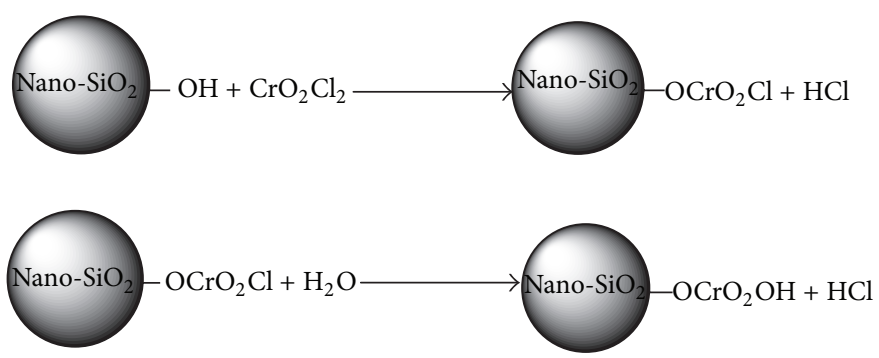

SCHEME 2: Preparation of nano solid acid and $\mathrm{HCl}$.

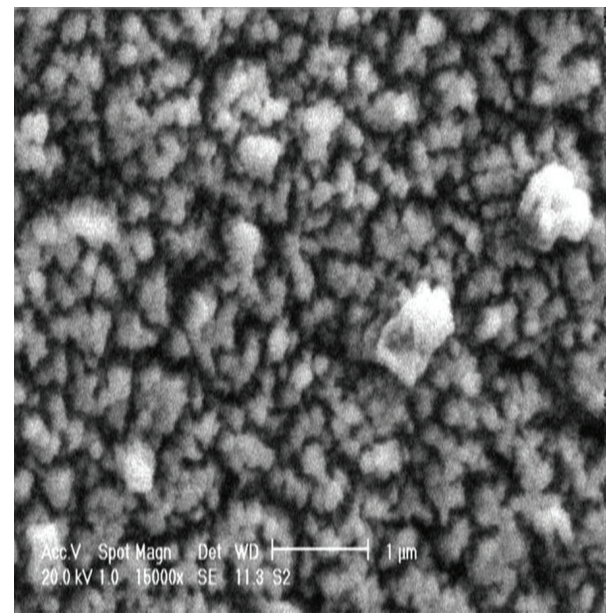

Figure 1: Scanning Electron Microscope (SEM) image of nanoSCA/resolution 15000X.

Electrothermal IA 9100 Digital Melting Point apparatus. ${ }^{1} \mathrm{H}$ and ${ }^{13} \mathrm{C}$ NMR spectra were recorded on Bruker 400 ultrashield NMR spectrometer $\left(\mathrm{CDCl}_{3}\right.$ and acetone- $\left.d_{6}\right)$. FT-IR spectra were recorded on a magna-550 Nicolet. GC-Mass analysis was performed on a GC-Mass model; 5973 network mass selective detector and GC 6890 egilent mass spectra (GC system Hp-5 capillary $30 \mathrm{~m} \times 530 \mu \mathrm{m} \times 15 \mu \mathrm{m}$ nominal) were obtained with a Massens POEKTROMETER CH-7A VARIN MAT BREMEN spectrometer. The Scanning Electron Microscope (SEM) picture of nano-SCA is recorded with $15000 \mathrm{X}$. All the yields were calculated from isolated products, and GC was used to establish their purities. HPLC analysis employed an internal standard method based on the absorbance of a product.

2.1. Preparation of Nano Silica Chromic Acid. A $500 \mathrm{~mL}$ suction flask equipped with a constant-pressure dropping funnel and a gas inlet tube for conducting $\mathrm{HCl}$ gas over an adsorbing solution (i.e., water) was used. It was charged with nano silica gel $(5 \mathrm{~g})$. Then, chromyl chloride $(10 \mathrm{~g})$ was added dropwise over a period of $30 \mathrm{~min}$ at room temperature. $\mathrm{HCl}$ gas evolved from the reaction vessel immediately. After the addition was complete, the mixture was shaken for $30 \mathrm{~min}$. Nano silica chromic acid as a dark brown solid, $12 \mathrm{~g}$, was obtained.

2.2. General Procedure for the Synthesis of Pyrano- and Furanoquinolines. A mixture of aldehyde ( $1 \mathrm{mmol})$, aryl amine ( $1 \mathrm{mmol})$, and 3,4-dihydro-2H-pyran or 2,3-dihydrofuran $(2 \mathrm{mmol})$ in THF $(10 \mathrm{~mL})$, nano silica chromic acid (nano SCA) $(0.07 \mathrm{~g})$ was added and the mixture stirred at room temperature for an appropriate time. After completion (followed by TLC), the solvent was removed under reduced pressure using a rotary evaporator. The crude material was subjected to column chromatography over silica gel eluting with Hexane/EtOAc (2-10\%) to afford the pure pyrano- or furoquinolines.

\subsection{Selected Spectra}

(4aS,5S)-5-Phenyl-3,4,4a,5,6,10b-hexahydro-2H-pyrano[3,2c]quinoline (4d). M.p. $129-130^{\circ} \mathrm{C},{ }^{1} \mathrm{H} \mathrm{NMR}\left(\mathrm{CDCl}_{3}\right) \delta / \mathrm{ppm}$ : 1.25-1.60 (m, 3H), 1.80-1.90 (m, 1H), 2.00-2.10 (m, 1H), 3.75 $(\mathrm{dt}, 1 \mathrm{H}, J=11.5,2.5 \mathrm{~Hz}), 4.00-4.10(\mathrm{~m}, 2 \mathrm{H}), 4.40(\mathrm{~d}, J=2.5 \mathrm{~Hz}$, $1 \mathrm{H}), 4.75(\mathrm{~d}, J=10.8 \mathrm{~Hz}, 1 \mathrm{H}), 6.50(\mathrm{~d}, J=8.0 \mathrm{~Hz}, 1 \mathrm{H}), 6.70(\mathrm{t}$, $J=7.5 \mathrm{~Hz}, 1 \mathrm{H}), 7.10$ (t, $J=7.5 \mathrm{~Hz}, 1 \mathrm{H}), 7.25(\mathrm{~d}, J=8.0 \mathrm{~Hz}, 1 \mathrm{H})$, 
Organic Chemistry International

3

TABLE 1: Synthesis of pyrano- and furoquinolines using nano silica chromic acid (nano-SCA) catalyst in THF as solvent and at room temperature.

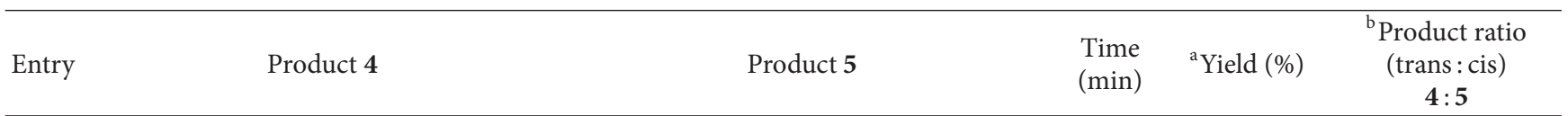

1

2

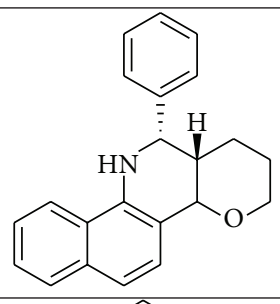

3

4

5
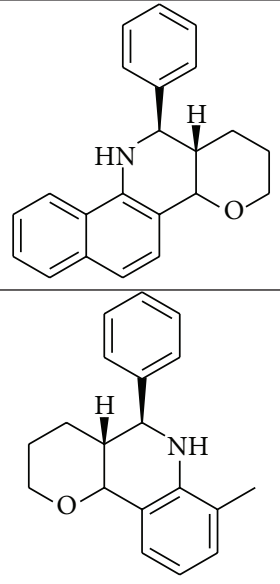

55

89

70

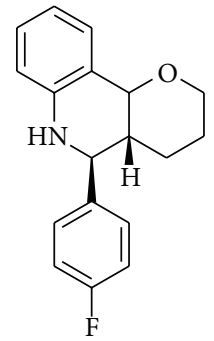

95

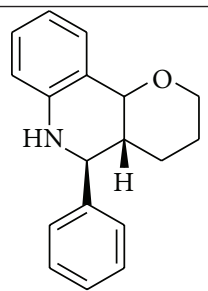

65

94

$90: 10$

70

90

$85: 15$

6<smiles>Fc1ccc2c(c1)C1OCCC[C@H]1[C@H](c1ccccc1)N2</smiles>

86

91.5

$87: 13$ 
TABLE 1: Continued.

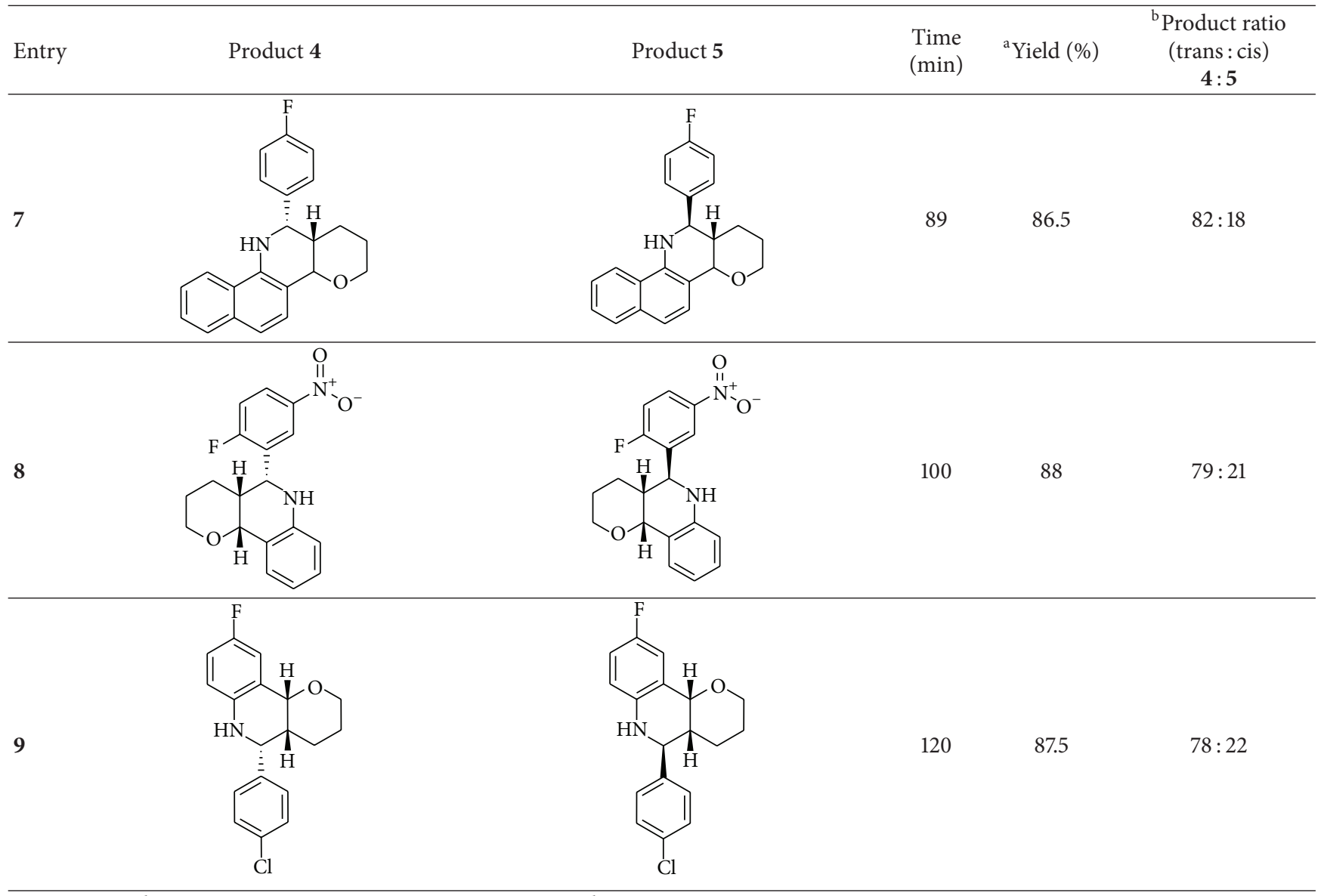

${ }^{\mathrm{a}}$ Isolated yields. ${ }^{\mathrm{b}}$ Isomers were separated by column chromatography. ${ }^{\mathrm{b}}$ Ratio of the product was determined from the crude ${ }^{1} \mathrm{H}$ NMR spectra.

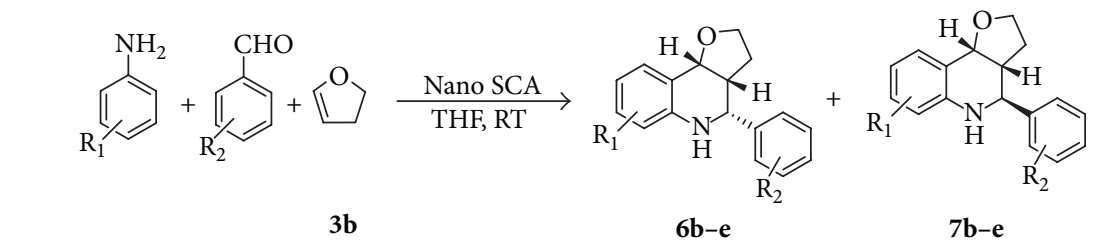

nano silica chromic acid (Nano SCA)

Scheme 3: Synthesis of furo[3,2-c] quinolines using nano silica chromic acid (nano-SCA) catalyst.

$7.40-7.55(\mathrm{~m}, 5 \mathrm{H}) .{ }^{13} \mathrm{CNMR}\left(\mathrm{CDCl}_{3}\right) \delta / \mathrm{ppm}: 22.3,24.4,39.3$, $55.0,69.2,74.5,114.2,117.4,120.5,127.7,127.9,128.5,129.4$, 130.9, 142.2, 144.5. IR $\left(\mathrm{KBr}, \mathrm{cm}^{-1}\right): 3325,2941,2864,1607$, $1482,1088 \mathrm{~cm}^{-1}$. Calcd. mass fractions of elements, $w / \%$, for $\mathrm{C}_{18} \mathrm{H}_{19} \mathrm{NO}$ : C, 81.48; H, 7.22; N, 5.28. Found: C, 81.51; H, 7.23; N, 5.32. EIMS: $m / z: 265 \mathrm{M}^{+}, 234,220,194,129,117,91,77$.

(4aR,5S)-5-Phenyl-3,4,4a,5,6,10b-hexahydro-2H-pyrano[3,2c]quinoline (5d). M.p. $129-130{ }^{\circ} \mathrm{C},{ }^{1} \mathrm{H}$ NMR $\left(\mathrm{CDCl}_{3}\right) \delta / \mathrm{ppm}$ : 1.25 (m, 1H), 1.55-1.70 (m, 3H), 2.10-2.20 (m, 1H), $3.42(\mathrm{dt}$, $1 \mathrm{H}, J=11.3,2.4 \mathrm{~Hz}), 3.56(\mathrm{dd}, 1 \mathrm{H}, J=11.3,2.4 \mathrm{~Hz}), 3.80(1 \mathrm{H}$, $\mathrm{NH}), 4.70(\mathrm{~d}, J=2.7 \mathrm{~Hz}, 1 \mathrm{H}), 5.30(\mathrm{~d}, J=5.6 \mathrm{~Hz}, 1 \mathrm{H}), 6.57$ (d, $J=8.0 \mathrm{~Hz}, 1 \mathrm{H}), 6.76(\mathrm{t}, J=8.0 \mathrm{~Hz}, 1 \mathrm{H}), 7.04(\mathrm{t}, J=7.8 \mathrm{~Hz}, 1 \mathrm{H})$, 7.25-7.45 (m, 6H); ${ }^{13} \mathrm{CNMR}\left(\mathrm{CDCl}_{3}\right) \delta / \mathrm{ppm}$ : 18.1, 25.7, 39.0,
59.4, 60.7, 72.8, 114.4, 118.0, 120.4, 126.9, 127.5, 127.7, 128.0, $128.4,141.2,145.2$. IR $\left(\mathrm{KBr}, \mathrm{cm}^{-1}\right): 3340,2970,2850,1610$, $1490,1090 \mathrm{~cm}^{-1}$. Calcd. mass fractions of elements, $w / \%$, for $\mathrm{C}_{18} \mathrm{H}_{19} \mathrm{NO}$ : C, 81.48; H, 7.20; N, 5.28. Found: C, 81.50; H, 7.24; N, 5.30. EIMS: $m / z: 265 \mathrm{M}^{+}, 234,220,194,129,117,91,77$.

$\left(3 a R^{*}, 4 R^{*}, 9 b R^{*}\right)-4$-(4-Bromophenyl)-2,3,3a,4,5,9b-hexahydrofuro[3,2-c] quinoline (6b). M.p. $210-215^{\circ} \mathrm{C}$; IR (neat, $\mathrm{cm}^{-1}$ ): 3416, 1617, 1485, 1353; ${ }^{1} \mathrm{H} \mathrm{NMR}\left(\mathrm{CDCl}_{3}\right) \delta / \mathrm{ppm}$ : 7.53-7.42 (m, $2 \mathrm{H}), 7.36-7.26(\mathrm{~m}, 3 \mathrm{H}), 7.03(\mathrm{dt}, 1 \mathrm{H}, J=1.3,8.4 \mathrm{~Hz}), 6.77(\mathrm{t}$, $1 \mathrm{H}, J=7.5 \mathrm{~Hz}), 6.52(\mathrm{~d}, 1 \mathrm{H}, J=7.9 \mathrm{~Hz}), 5.2(\mathrm{~d}, 1 \mathrm{H}, J=7.7 \mathrm{~Hz})$, $4.65(\mathrm{~d}, 1 \mathrm{H}, J=2.6 \mathrm{~Hz}), 3.81-3.51(\mathrm{~m}, 1 \mathrm{H}), 2.75-2.65(\mathrm{~m}, 1 \mathrm{H})$, 2.23-2.07 (m, 1H). $1.50(\mathrm{~m}, 1 \mathrm{H}),{ }^{13} \mathrm{CNMR}\left(\mathrm{CDCl}_{3}\right) \delta / \mathrm{ppm}$ : $28.5,49.4,58.4,68.5,84.6,84.5,110.4,119.3,120.3,126.6$, 
TABLE 2: Synthesis of furoquinolines using nano silica chromic acid (nano-SCA) catalyst in THF as solvent and at room temperature.

Entry

${ }^{a}$ Isolated yields. ${ }^{b}$ Isomers were separated by column chromatography. ${ }^{b}$ Ratio of the product was determined from the crude ${ }^{1} \mathrm{H}$ NMR spectra.

TABLE 3: The effectiveness of varities solvents in the synthesis of pyranoquinolines (Table 1, Entry 4, compounds $\mathbf{4 a}$ and $\mathbf{5 a}$ ) using nano silica chromic acid (nano-SCA) catalyst.

\begin{tabular}{lcccc}
\hline Entry & Solvent & $\begin{array}{c}\text { Time } \\
(\mathrm{min})\end{array}$ & $\begin{array}{c}{ }^{\mathrm{a}} \text { Yield } \\
(\%)\end{array}$ & $\begin{array}{c}{ }^{\mathrm{b}} \text { Product ratio } \\
\mathbf{4 a}: \mathbf{5} \mathbf{a} \\
\text { (trans:cis) }\end{array}$ \\
\hline $\mathbf{1}$ & $\mathrm{THF}$ & 65 & 94 & $90: 10$ \\
$\mathbf{2}$ & $\mathrm{CCl}_{4}$ & 91 & 72.5 & $81: 19$ \\
$\mathbf{3}$ & $\mathrm{CHCl}_{3}$ & 74 & 69 & $80: 20$ \\
$\mathbf{4}$ & $\mathrm{CH}_{2} \mathrm{Cl}_{2}$ & 69 & 73 & $73: 27$ \\
$\mathbf{5}$ & $\mathrm{DMF}_{\mathbf{6}}$ & 115 & 68 & $65: 35$ \\
$\mathbf{6}$ & $\mathrm{DMSO}_{\mathbf{8}}$ & 125 & 52 & $62: 38$ \\
$\mathbf{8}$ & $\mathrm{CH}_{3} \mathrm{CN}$ & 76 & 58 & $67: 33$ \\
$\mathbf{9}$ & $\mathrm{C}_{6} \mathrm{H}_{5} \mathrm{CH}$ & 87 & 70 & $69: 31$ \\
$\mathbf{1 0}$ & Free & 95 & 59 & $62: 28$ \\
\hline
\end{tabular}

${ }^{\mathrm{a}}$ Isolated yield. ${ }^{\mathrm{b}}$ Isomers were separated by column chromatography.

${ }^{b}$ Ratio of the product was determined from the crude ${ }^{1} \mathrm{H}$ NMR spectra.

128.5, 131.5, 139.5, 145.7. EIMS $m / z(\%): 330\left(\mathrm{M}^{+}\right)$. Calcd. mass fractions of elements, $w / \%$, for $\mathrm{C}_{17} \mathrm{H}_{16} \mathrm{BrNO}$ : C, 61.82; $\mathrm{H}$, 4.86; N, 4.22. Found: C, 61.61; H, 4.73; N, 4.12.

$\left(3 a R^{*}, 4 S^{*}, 9 b R^{*}\right)-4-(4-B r o m o p h e n y l)-2,3,3 a, 4,5,9 b$-hexahydrofuro[3,2-c] quinoline (7b). M.p. $142-147^{\circ} \mathrm{C}$; IR (neat, $\mathrm{cm}^{-1}$ ): 3417, 1617, 1352; ${ }^{1} \mathrm{H}$ NMR $\left(\mathrm{CDCl}_{3}\right) \delta / \mathrm{ppm}$ : 7.51-7.46 (m, 2H), $7.35-7.30(\mathrm{~m}, 3 \mathrm{H}), 7.08(\mathrm{dt}, 1 \mathrm{H}, J=1.5,9.0 \mathrm{~Hz}), 6.77(\mathrm{t}, 1 \mathrm{H}$, $J=7.5 \mathrm{~Hz}), 6.57(\mathrm{~d}, 1 \mathrm{H}, J=7.5 \mathrm{~Hz}), 4.53(\mathrm{~d}, 1 \mathrm{H}, J=5.2 \mathrm{~Hz})$,
4.03-3.95 (m, 2H), 3.84-3.71 (m, 2H), 2.42-2.30 (m, $1 \mathrm{H})$, $2.06-1.93(\mathrm{~m}, 1 \mathrm{H}), 1.71-1.60(\mathrm{~m}, 1 \mathrm{H})$. EIMS $\mathrm{m} / z(\%): 328$ $\left(\mathrm{M}^{+}-1\right) .{ }^{13} \mathrm{CNMR}\left(\mathrm{CDCl}_{3}\right) \delta / \mathrm{ppm}: 28.7,49.6,58.2,68.7$, $84.4,110.5,119.7,120.3,125.7,128.4,128.9,131.3$. EIMS $m / z$ (\%): $330\left(\mathrm{M}^{+}\right)$. Calcd. mass fractions of elements, $w / \%$, for $\mathrm{C}_{17} \mathrm{H}_{16}$ BrNO: C, 61.82; H, 4.85; N, 4.22. Found: C, 61.63; H, $4.77 ; \mathrm{N}, 4.16 .139 .6,145.7$.

\section{Results and Discussion}

A convenient, rapid, and one-pot method for the Aza-DielsAlder reactions of aldimines with dihydropyran or dihydrofuran to afford the corresponding pyrano and furo[3,2-c] quinolines in high yields with high diastereoselectivity in a short period of time has been developed. We now report our observations on the synthesis of pyrano- and furoquinolines by a one-pot three-component coupling of anilines (1), benzaldehydes (2), and 3,4-dihydro- $2 \mathrm{H}$-pyran or 2,3-dihydrofuran (3a, b) catalyzed by nano silica chromic acid (nanoSCA) at room temperature (Scheme 1).

Nano-SCA is formed via the reaction between nano silica gel (mesh $20 \mathrm{~nm}$ ) and chromyl chloride, $\mathrm{CrO}_{2} \mathrm{Cl}_{2}$. Then, $\mathrm{HCl}$ and $\mathrm{SiO}_{2}-\mathrm{CrO}_{3} \mathrm{H}$ are formed in situ by the reaction between nano-SCA and $\mathrm{H}_{2} \mathrm{O}$ in wet $\mathrm{SiO}_{2}$ (Scheme 2).

The Scanning Electron Microscope (SEM) picture of nano-SCA is recorded with $15000 \mathrm{X}$ (Figure 1).

In a typical procedure, benzaldehyde and aniline were reacted with 3,4-dihydro- $2 \mathrm{H}$-pyran in the presence of nano silica chromic acid (nano-SCA) catalyst in THF at room temperature. To our surprise, the reaction yielded the corresponding pyrano[3,2-c] quinoline within $65 \mathrm{~min}$ as a mixture 
TABLE 4: The effectiveness of temperature in the synthesis of pyranoquinolines (Table 1, Entry 4, compounds $\mathbf{4 a}$ and $\mathbf{5 a}$ ) in THF as solvent.

\begin{tabular}{lccccc}
\hline Entry & Catalyst & $\begin{array}{c}\text { Temp } \\
\left({ }^{\circ} \mathrm{C}\right)\end{array}$ & $\begin{array}{c}{ }^{\mathrm{a}} \text { Yield } \\
(\%)\end{array}$ & $\begin{array}{c}\text { Time } \\
(\mathrm{min})\end{array}$ & $\begin{array}{c}{ }^{\mathrm{b}} \text { Product ratio } \\
\mathbf{4 a}: \mathbf{5 a} \\
\text { (trans }: \text { cis })\end{array}$ \\
\hline $\mathbf{1}$ & Nano SCA & 25 & 94 & 65 & $90: 10$ \\
$\mathbf{2}$ & Nano SCA & Reflux & 97.5 & 52 & $92: 8$ \\
$\mathbf{3}$ & $\mathrm{ZnO}$ & Reflux & 64.5 & 91 & $68: 32$ \\
$\mathbf{4}$ & $\mathrm{ZnO}$ & 25 & 60.5 & 109 & $61: 39$ \\
$\mathbf{5}$ & $\mathrm{H}_{2} \mathrm{SO}_{4}$ & Reflux & 86 & 88 & $84: 26$ \\
$\mathbf{6}$ & $\mathrm{H}_{2} \mathrm{SO}_{4}$ & 25 & 80 & 99 & $79: 21$ \\
$\mathbf{7}$ & ${\mathrm{Bi}(\mathrm{OTf})_{3}}_{\mathbf{8}}$ & Reflux & 79.5 & 92 & $71: 39$ \\
$\mathbf{8}$ & $\mathrm{Yb}(\mathrm{OTf})_{3}$ & Reflux & 84.5 & 96 & $66: 34$ \\
$\mathbf{9}$ & Free & Reflux & 43 & 116 & $58: 42$ \\
$\mathbf{1 0}$ & Free & 25 & 36 & 168 & $49: 51$ \\
\hline
\end{tabular}

${ }^{\mathrm{a}}$ Isolated yield. ${ }^{\mathrm{b}}$ Isomers were separated by column chromatography.

${ }^{b}$ Ratio of the product was determined from the crude ${ }^{1} \mathrm{H}$ NMR spectra.

of cis- and trans-isomers in the ratio of $10: 90$, in an overall yield of $94 \%$. Easy separation of the isomers was achieved by chromatography over silica gel (Scheme 1). We could establish the structures of these isomers based on ${ }^{1} \mathrm{H}$ NMR data and the IR spectrum is especially strong differentiating isomers of diverse functional groups, being the spectroscopy of choice for instant classification of molecules. And the ratio of the isomers obtained in each reaction was determined from the ${ }^{1}$ HNMR spectrum of the crude product, and the structures of the products were characterized on the basis of spectroscopic (IR, ${ }^{1} \mathrm{H}$ NMR, ${ }^{13} \mathrm{C} \mathrm{NMR}$, and GC-MS) data of the pure compounds from column chromatography (Scheme 1, compounds $\mathbf{4} \mathbf{a}-\mathbf{j}$ and $\mathbf{5} \mathbf{a}-\mathbf{j}$ ). All the reactions involving various aldehydes containing electron donating and electron withdrawing substituents formed imine in situ, and in all cases, the imines generated from aromatic aldehydes and anilines reacted with dihydropyran, and the three-component one-pot reaction proceeded to give the corresponding pyranoquinolines in high yields and with high diastereoselectivity. The results are listed in Table 1.

The reaction proceeded in a short period of time and afforded the corresponding furo[3,2-c] quinolines a mixture of cis- and trans-isomers (Scheme 3, compounds 6 and 7) which could be separated and purified by column chromatography over silica gel to give a solid that was defined by GC-MS, IR, and ${ }^{1} \mathrm{H}$ NMR (Scheme 3 ), and the results are listed in Table 2.

Several aldimines (formed in situ from aromatic aldehydes and anilines in THF) reacted smoothly with 2,3-dihydrofuran using nano silica chromic acid (nano-SCA) catalyst to afford the corresponding furano[3,2-c] quinolines as cis/trans mixtures in $87 \%-92 \%$ yield (Scheme 3 and Table 2 ). Also, the structures of the products were established on the basis of spectroscopic (IR, ${ }^{1} \mathrm{H}$ NMR, ${ }^{13} \mathrm{C} \mathrm{NMR}$, and GC-MS) data of the pure compounds (Scheme 3, compounds 6 and 7).

To further optimize the reaction condition in terms of solvent, we tried the reaction in various solvents and also without solvent. It was noticed that THF as solvent appears to be
TABLE 5: The effectiveness of varities catalysts in the synthesis of pyranoquinolines (Table 1, Entry $\mathbf{4}$, compounds $\mathbf{4 a}$ and $\mathbf{5 a}$ ) in THF as solvent.

\begin{tabular}{lcccc}
\hline Entry & Catalyst & $\begin{array}{c}{ }^{\mathrm{a}} \text { Yield } \\
(\%)\end{array}$ & $\begin{array}{c}\text { Time } \\
(\mathrm{min})\end{array}$ & $\begin{array}{c}{ }^{\mathrm{b}} \text { Product ratio } \\
\mathbf{4 a}: \mathbf{5} \mathbf{a} \\
\text { (trans }: \text { cis })\end{array}$ \\
\hline $\mathbf{1}$ & Nano SCA & 94 & 65 & $90: 10$ \\
$\mathbf{2}$ & $\mathrm{ZnO}$ & 61 & 91 & $64: 36$ \\
$\mathbf{3}$ & $\mathrm{H}_{2} \mathrm{SO}_{4}$ & 81.5 & 88 & $80: 20$ \\
$\mathbf{4}$ & ${\mathrm{Bi}(\mathrm{OTf})_{3}}$ & 77 & 92 & $66: 34$ \\
$\mathbf{5}$ & $\mathrm{Yb}(\mathrm{OTf})_{3}$ & 78 & 96 & $61: 39$ \\
$\mathbf{6}$ & Free & 36.5 & 145 & $53: 47$ \\
\hline${ }^{\mathrm{a}}$ Isolated yield. ${ }^{\mathrm{b}}$ Isomers were separated by column chromatography. \\
${ }^{\mathrm{b}}$ Ratio of the product was determined from the crude ${ }^{1} \mathrm{H}$ NMR spectra.
\end{tabular}

superior in improving the trans selectivity of the product (Table 1, Entry 5). The results are summarized in Table 3 and the major isomer is $\mathbf{4 a}$ (trans-isomer) $[16,17]$.

When the experiment was conducted at room temperature, a good and convenient amount of the corresponding product was generated (Table 4, Entry 1, and Tables 1 and 2). Upon heating (reflux conditions), however, the reaction was greatly accelerated (Table 4, Entries 2, 3, 5, and 7-9) and with higher yield (Table 4, Entry 2). The major isomer often depends on the reaction temperature. Higher temperature gave more of the thermodynamically stable trans-isomer products, while lower temperatures resulted in fast formation of the kinetically favored cis-isomer products (94\% yield), (Table 4, Entry 1). A moderate yield (97.5\%) was obtained accompanied by high trans selectivity of the product $92: 8$ (Table 4, Entry 2).

Initially, we compared the catalytic performance of $\mathrm{H}_{2} \mathrm{SO}_{4}, \mathrm{Yb}(\mathrm{OTf})_{3}, \mathrm{Bi}(\mathrm{OTf})_{3}, \mathrm{ZnO}$, and nano silica chromic acid (nano-SCA) catalyst, in the synthesis of pyrano- and furoquinolines. The results are shown in Table 5. The yield of product decreases in the following order:

$$
\begin{aligned}
(\text { Nano SCA }) & >\mathrm{H}_{2} \mathrm{SO}_{4}>\mathrm{Yb}(\mathrm{OTf})_{3} \\
& >\mathrm{Bi}(\mathrm{OTf})_{3}>\mathrm{ZnO}
\end{aligned}
$$

As could be seen, nano silica chromic acid catalyst is more effective than the other catalysts, and in the presence of this catalyst the highest yields of products are obtained. The results (Table 4) show that nano silica chromic acid catalyst is better with respect to yield and to reaction. In all cases, the nano silica chromic acid catalyst shows higher activity compared with other catalysts, $\mathrm{ZnO}, \mathrm{Bi}(\mathrm{OTf})_{3}, \mathrm{Yb}(\mathrm{OTf})_{3}$, and $\mathrm{H}_{2} \mathrm{SO}_{4}$ (Table 5, Entries 2-5). Nano silica chromic acid (nano-SCA) catalyst shows a higher selectivity, and this catalyst is an efficient solid acid catalyst for highly selective synthesis of pyrano- and furoquinolines.

\section{Conclusion}

Nano-SCA is noncorrosive and safe solid acid with easy separation and recovery from reaction mixture. We have synthesized azo pyrano- and furoquinolines using nano silica 
chromic acid as a solid acid at room temperature and in good yields, under mild reaction conditions, with high diastereoselectivity. The yields of products were good to excellent, and the reaction times were very suitable. This paper describes a novel and efficient method for the synthesis of pyrano- and furanoquinolines using nano-SCA as promoters.

\section{References}

[1] S. M. Weinreb, "Heterodienophile additions to dienes," in Comprehensive Organic Synthesis, B. M. Trost, I. Fleming, and L. A. Paquette, Eds., vol. 5, p. 401, Pergamon Press, Oxford, UK, 1991.

[2] R. W. Carling, P. D. Leeson, A. M. Moseley et al., "2-Carboxytetrahydroquinolines. Conformational and stereochemical requirements for antagonism of the glycine site on the NMDA receptor," Journal of Medicinal Chemistry, vol. 35, no. 11, pp. 1942-1953, 1992.

[3] M. Ramesh, P. S. Mohan, and P. Shanmugam, "A convenient synthesis of flindersine, atanine and their analogues," Tetrahedron, vol. 40, no. 20, pp. 4041-4049, 1984.

[4] J. Sharada, Y. R. Kumari, and M. Kanakalingeswara Rao, "Synthesis and biological activity of furoquinolines: 2-aroyl-4-methyl/4,6-dimethyl-3-phenyl-furo [3,2-c] quinolines," Indian Journal of Pharmaceutical Sciences, vol. 49, no. 1, pp. 17-21, 1987.

[5] D. L. Boger and S. M. Weinreb, Hetero Diels-Alder Methodology in Organic Synthesis, Chapters 2 and 9, Academic, San Diego, Calif, USA, 1987.

[6] P. Buonora, J. C. Olsen, and T. Oh, "Recent developments in imino Diels-Alder reactions," Tetrahedron, vol. 57, pp. 6099-6138, 2001.

[7] J. V. Johnson, B. S. Rauckman, D. P. Baccanari, and B. Roth, "2,4-diamino-5-benzylpyrimidines and analogues as antibacterial agents. 12. 1,2-dihydroquinolylmethyl analogues with high activity and specificity for bacterial dihydrofolate reductase," Journal of Medicinal Chemistry, vol. 32, no. 8, pp. 1942-1949, 1989.

[8] R. Annunziata, M. Cinquini, F. Cozzi, V. Molteni, and O. Schupp, "A new multicomponent synthesis of 1,2,3,4-tetrahydroquinolines," Tetrahedron, vol. 53, no. 28, pp. 9715-9726, 1997.

[9] G. Babu and P. T. Perumal, "Convenient synthesis of pyrano[3,2c] quinolines and indeno[2,1- c] quinolines by imino Diels-Alder reactions," Tetrahedron Letters, vol. 39, no. 20, pp. 3225-3228, 1998.

[10] L. S. Povarov, " $\alpha \beta$-unsaturated ethers and their analogues in reactions of diene synthesis," Russian Chemical Reviews, vol. 36, no. 9, p. 656, 1967.

[11] M. A. Zolfigol, "Silica sulfuric acid/ $\mathrm{NaNO}_{2}$ as a novel heterogeneous system for production of thionitrites and disulfides under mild conditions," Tetrahedron, vol. 57, no. 46, pp. 9509-9511, 2001.

[12] M. A. Zolfigol, B. F. Mirjalili, A. Bamoniri et al., "Nitration of aromatic compounds on silica sulfuric acid," Bulletin of the Korean Chemical Society, vol. 25, no. 9, pp. 1414-1416, 2004.

[13] M. A. Zolfigol, M. Bagherzadeh, S. Mallakpour et al., "Mild and heterogeneous oxidation of urazoles to their corresponding triazolinediones via in situ generation $\mathrm{Cl}^{+}$using silica sulfuric $\mathrm{acid} / \mathrm{KClO}_{3}$ or silica chloride/oxone system," Catalysis Communications, vol. 8, no. 3, pp. 256-260, 2007.

[14] M. A. Zolfigol, R. Ghorbani-Vaghei, S. Mallakpour, G. Chehardoli, A. G. Choghamarani, and A. H. Yazdi, "Simple, convenient and heterogeneous method for conversion of urazoles to triazolinediones using $\mathrm{N}, \mathrm{N}, \mathrm{N}^{\prime}, \mathrm{N}^{\prime}$-tetrabromobenzene-1,3disulfonylamide or trichloromelamine under mild and heterogeneous conditions," Synthesis, no. 10, pp. 1631-1634, 2006.

[15] A. R. Hajipour, A. Zarei, L. Khazdooz, S. A. Pourmousavi, and A. E. Ruoho, "Silicasulfuric acid/ $\mathrm{NaNO}_{2}$ as a new reagent for deprotection of S,S-acetals under solvent-free conditions," Bulletin of the Korean Chemical Society, vol. 26, no. 5, pp. 808-810, 2005.

[16] E. Boanini, P. Torricelli, M. Gazzano, R. Giardino, and A. Bigi, "Nanocomposites of hydroxyapatite with aspartic acid and glutamic acid and their interaction with osteoblast-like cells," Biomaterials, vol. 27, no. 25, pp. 4428-4433, 2006.

[17] G. Sabitha, M. S. K. Reddy, K. Arundhathi, and J. S. Yadav, "VCl3-Catalyzed aza-Diels-Alder reaction: one-pot synthesis of pyrano[3,2-c]quinolines and furo[3,2-c] quinolines," Arkivoc, vol. 2006, no. 6, pp. 153-160, 2006. 

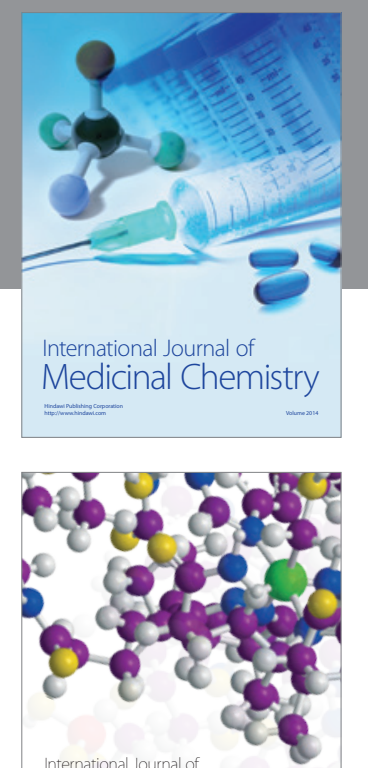

\section{Carbohydrate} Chemistry

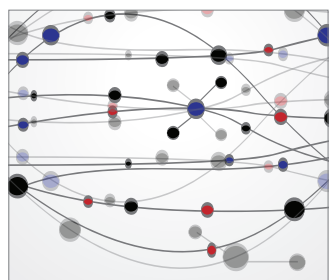

The Scientific World Journal
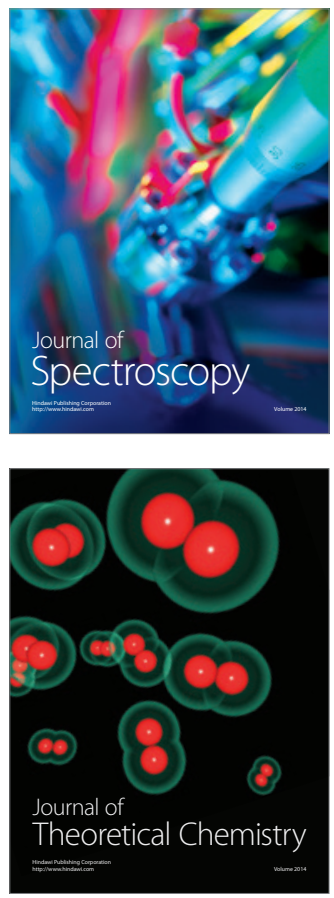


Submit your manuscripts at

http://www.hindawi.com

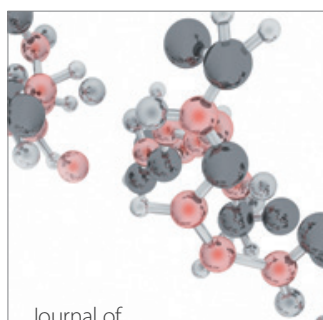

Analytical Methods

in Chemistry

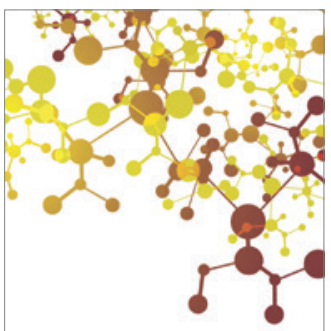

Journal of

Applied Chemistry

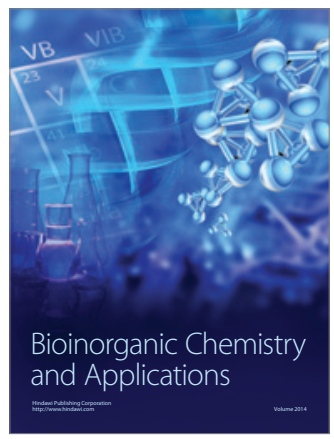

Inorganic Chemistry
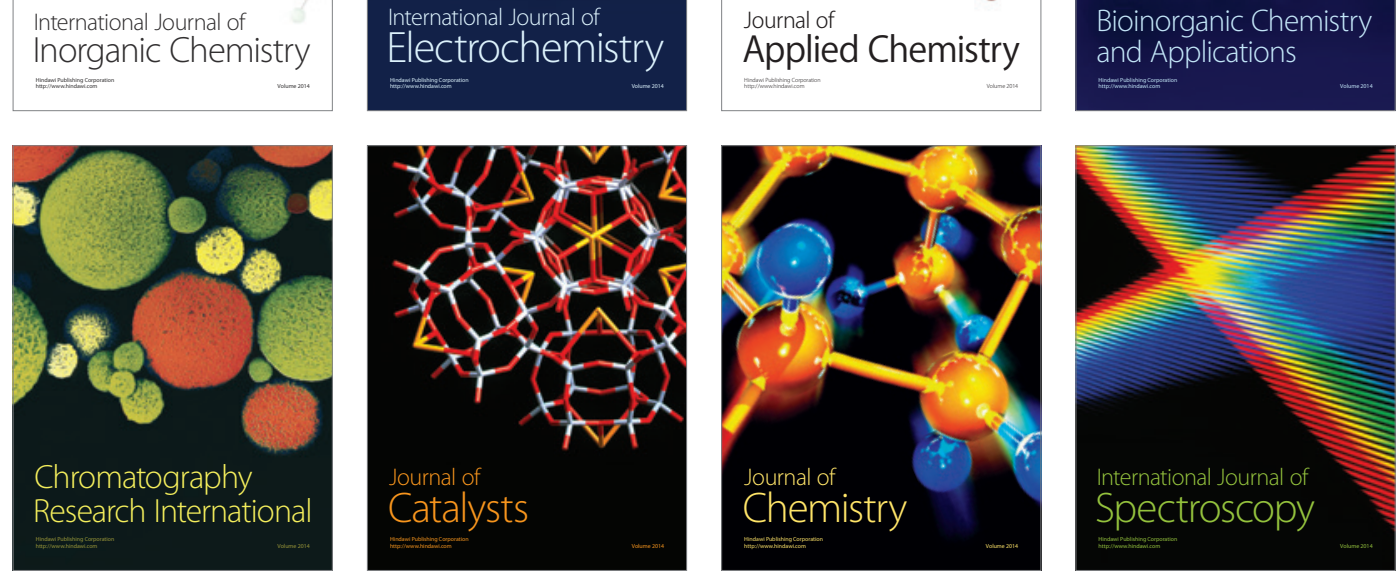